Article

\title{
Effects of Seasonality, Tree Species and Urban Green Space on Deciduous Leaf Litter Decomposition in Lithuania
}

\author{
Tadas Vaidelys, Lina Straigytė and Michael Manton * \\ Institute of Forest Biology and Silviculture, Vytautas Magnus University, Studentu 11, Akademija, \\ LT-53361 Kaunas, Lithuania; tadas.vaidelys@vdu.lt (T.V.); lina.straigyte@vdu.lt (L.S.) \\ * Correspondence: michael.manton@vdu.lt
}

Received: 11 February 2020; Accepted: 10 March 2020; Published: 12 March 2020

check for updates

\begin{abstract}
Understanding ecological processes and environmental change in different urban green spaces is an important challenge to secure human well-being. The variety of urban green spaces provides a platform to generate knowledge on how urban environments affect tree leaf decomposition and quality. We measured the leaf litter decomposition of four dominant native deciduous tree species from five different urban green spaces over three time periods in Kaunas, Lithuania. Using the modified litter bag technique, we calculated the decomposition of 60 leaf litter samples for 4, 8, and 12 months respectively. For each leaf litter sample, we determined total $\mathrm{N}$, total $\mathrm{P}$, and organic $\mathrm{C}$. Results indicated that the decomposition of leaf litter amongst tree species, urban green spaces and seasonality (time) were significantly different. The leaf litter of Betula pendula and Acer platanoides from street green spaces decomposed fastest during the spring-summer period. Quercus robur showed small but significant leaf litter loss differences between the green spaces, with the leaf litter from peri-urban forest decomposing the fastest. A decreased C:N ratio for Q. robur leaf litter showed accelerated leaf litter decay. In conclusion, our results show that the ecological processes of leaf litter decomposition, differs between tree species, type of urban green spaces and seasonality and thus must be considered in urban town planning to help maintain urban environments.
\end{abstract}

Keywords: city trees; deciduous trees; green infrastructure; leaf litter quality; nutrient cycle; parks; peri-urban forest; street trees; urban environmental processes

\section{Introduction}

Urban environments can influence vegetation richness, species composition and tree health through heat accumulation, building density, the level of traffic, and the degree of drainage and soil waterproofing [1,2]. Trees provide many ecological processes and functions, such as the regulation of microclimates, abating air pollution, decorating urban spaces, creating species habitats, and delivering benefits for human well-being [3-5]. Research on European urban green spaces have shown that they are extremely modified $[6,7]$ and can cause changes in ecological processes. Understanding the effects of local human induced changes to climate, soil, water, and air quality in urban green spaces is challenging. Often, poor site conditions, artificial ecosystems, and a lack of professional tree maintenance creates unhealthy conditions for tree growth in urban areas [8,9]. Abiotic factors such as the use of anti-icing salt during winter, buildings, pavements, and utility trenching negatively affect tree health and longevity [10]. These perceived benefits for human well-being also modify the local environment by influencing tree growth, growing season duration, nutrient accumulation in leaves, and leaf litter decomposition, as well as other key processes [11,12]. Leaf litter decomposition is an important process that can provide an indicator of ecosystem function and health at various levels [13]. 
Leaf litter decomposition is a key biogeochemical process in both forest ecosystems and urban areas, which enriches the soil and local waterways with nutrients [14,15]. In relation to soil nutrients, Waring and Schlesinger [16] estimate that nutrients released during litter decomposition can provide between $69 \%-87 \%$ of the yearly essential elements required by trees. However, leaf litter decomposition in urban areas may ultimately contribute to the eutrophication of surface water through storm water runoff [14]. Both abiotic factors, such as climate (mainly temperature, soil moisture, and evapotranspiration) and litter quality (in particular nitrogen, lignin, and polyphenol concentrations, C:N and C:P ratios), and biotic factors such as soil organism activity determine leaf litter decomposition [17-20].

Urban green spaces are characterized by different abiotic and biotic factors. These factors may affect the nutrition quality of leaf litter, thus changing the food source for microbial decomposers. For example, Carreiro et al. [21] suggested that decomposer activity in peri-urban forests may be affected by both altered leaf litter quality and altered environments. Decomposition of leaf litter can be predicted by many factors; the C:N, C:P, and N:P ratios are the main recognized factors [22-24]. The decomposition rate is positively correlated with $\mathrm{C}$ and $\mathrm{N}$ concentrations, and negatively correlated with the C:N ratio of fresh leaf litter [25-28]. According to the hypothesis that $\mathrm{C}: \mathrm{N}$ ratio is a suitable predictor for decomposition rates [25,29], it seems likely that a lower C:N ratio may lead to an increase in $\mathrm{C}$ and $\mathrm{N}$ litter mineralization [30]. Thus, the activity of microbial decomposers is often limited by nitrogen $(\mathrm{N})$ availability.

Understanding the effects of environmental conditions and how they affect ecological processes is a crucial step in forming management strategies to cater for the needs of human well-being in urban areas. The aim of this study was to explore leaf litter decomposition of four deciduous tree species collected from five different urban green spaces. We hypothesized that leaf litter decomposition, as an ecological process, would be different based on i) tree species, ii) type of urban green space, iii) seasonality (e.g., time and duration) and iv) leaf litter nutrients.

\section{Materials and Methods}

\subsection{Site Description}

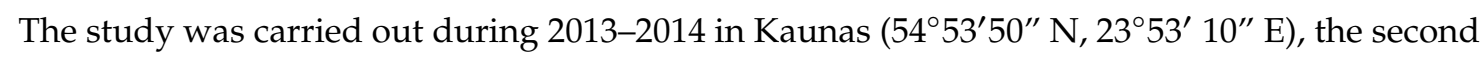
largest city in Lithuania with a population of 302,000 inhabitants and a territory of $158 \mathrm{~km}^{2}$. The average annual precipitation is $600 \mathrm{~mm}$. The average temperature in January is $-5.2^{\circ} \mathrm{C}$, and in July $+16.9^{\circ} \mathrm{C}$. The soil type of the sampled peri-urban forest consisted of both Luvisols and Podzols, and the soil profile of the urban green spaces was Anthrosols.

The design of this research focused on two aspects. Firstly, five different types of green spaces: 1) large urban parks $>1$ ha (LP); 2 ) small urban parks $<1$ ha (SP); 3 ) broad street greenery (minimum four lanes of traffic) (BSG); 4) narrow street greenery (maximum two lanes of traffic) (NSG); and 5) peri-urban forests (PUF). Secondly, we selected four common native deciduous tree species that were $>60( \pm 5)$ years of age: Norway maple (Acer platanoides L.), silver birch (Betula pendula Roth), small-leaved lime (Tilia cordata Mill.), and common oak (Quercus robur L.). Using a stratified sampling method, we selected 60 locations throughout the study area (12 sampling location for each type of green space). The number of sampling locations was limited to 60 , due to the availability of the five types of green spaces within Kaunas (Figure 1). 


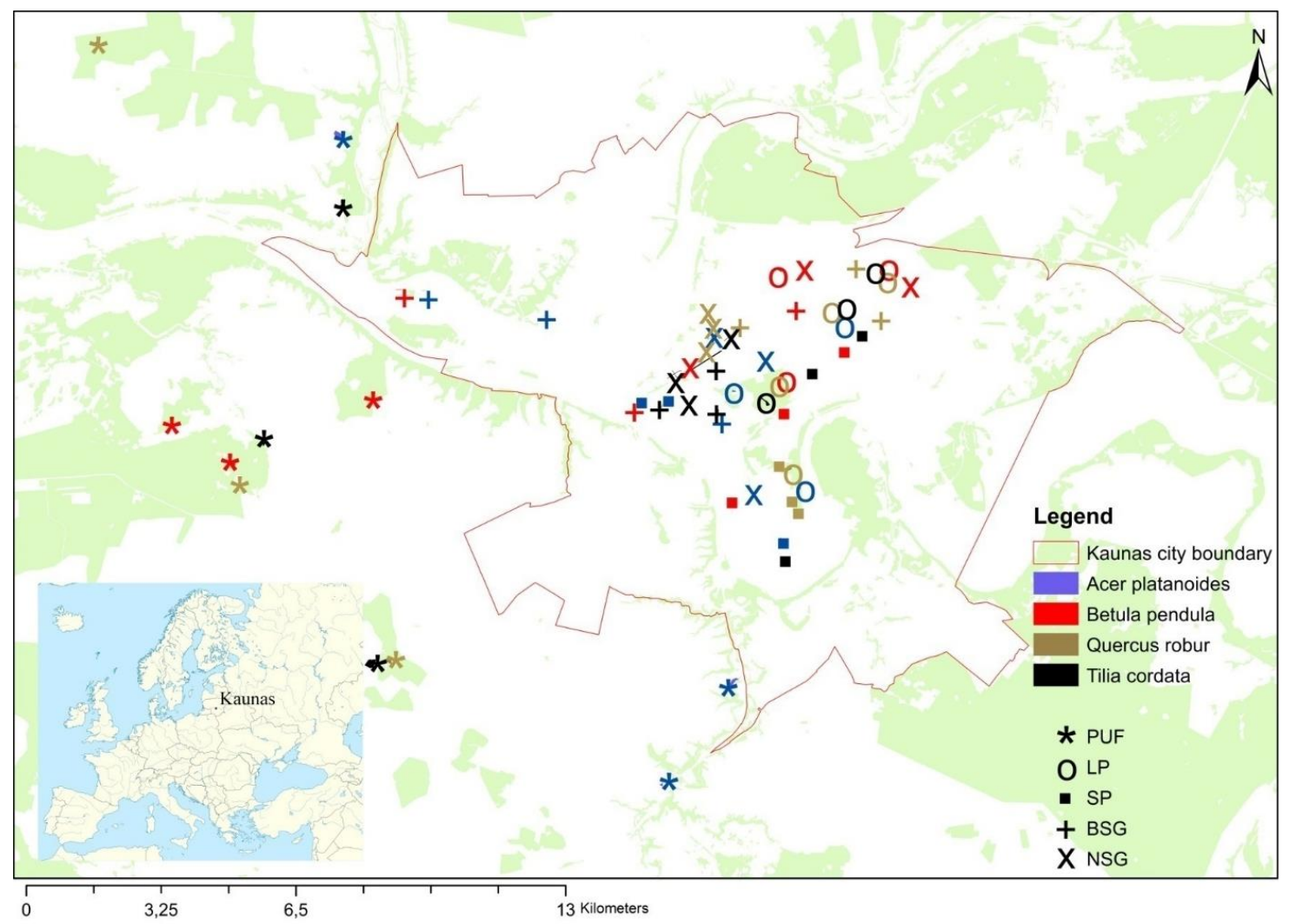

Figure 1. Locations of the deciduous leaf litter collection and urban green spaces in Kaunas, Lithuania. Note: $\mathrm{PUF}=$ Peri-urban forest, $\mathrm{LP}=$ Large park, $\mathrm{SP}=$ Small park, BSG = Broad street greenery, and NSG = Narrow street greenery.

\subsection{Leaf Litter Decomposition}

We used the modified litter bag technique to study leaf litter decomposition [31,32]. At the end of autumn in 2013, we collected leaf litter samples for each of the four tree species (T. cordata, A. platanoides, B. pendula, and Q. robur) from the five green space types. Fallen leaf litter was collected off the ground within 2 meters of the tree trunk. Following leaf litter collection, we dried all leaf litter samples at $30{ }^{\circ} \mathrm{C}$ and prepared $180(60 \times 3$ repeats) fiber mesh (bag size $20 \times 20 \mathrm{~cm}$, mesh size was $1.4 \mathrm{~mm})$ bags with 5 grams of leaf litter. Subsequently, we placed each leaf litter bag side by side on the ground, in a controlled peri-urban forest environment with the same environmental conditions on December 1st, 2013. The soil type of the control site was Luvisols. After 4 months (April 1st, 2014), 8 months (August 1st, 2014), and 12 months (December 1st, 2014) we collected 60 of the 180 leaf litter bags, respectively. Directly following each collection of the leaf litter bags, we analyzed and calculated their decomposition by measuring the loss in mass of each bag (i.e., 3 time periods). In total, we collected 180 samples (four tree species $x$ five green spaces $x$ three sampling times $x$ three replicates $=180$ ).

\subsection{Leaf Litter Quality}

Leaf litter chemical analyses were performed at the Agrochemical Research Laboratory of Lithuanian Research Centre for Agriculture and Forestry. For each leaf litter sample $(\mathrm{N}=180)$, we determined: total N (EU directive 72/199/EEC); total P (EU directive 71/393/EEC); organic C - by dry combustion at $900{ }^{\circ} \mathrm{C}$ with a CNS analyzer (ISO 10694: 1995).

\subsection{Statistical Data Analysis}

After determining that the data did not have a normal distribution, a non-parametric test was used to analysis the data [33]. As standard ANOVA is robust against departures from normality [34], 
we began the statistical analysis by firstly applying a two-factor ANOVA (urban green spaces, five levels, and tree species, four levels). We did this to test if the loss in litter mass amongst the various urban green spaces is dependent upon the tree species. Secondly, having found significant interactions, we then analyzed the data by each tree species separately using a non-parametric Kruskal-Wallis ANOVA test [35] to identify significant differences between the five different green spaces and the four deciduous tree species. Data analyses were performed using Statsoft Statistica 10.0 and Microsoft Excel.

\section{Results}

\subsection{Leaf Litter Decomposition of Four Tree Species in Time}

The total mean leaf litter loss in mass for each tree species, without differentiation of green spaces, showed large differences over 4, 8, and 12 months (Figure 2). Firstly, over these three periods, results showed that $Q$. robur leaf litter decomposed the slowest. In contrast, the highest leaf litter decomposition was recorded by A. platanoides over 4 months and B. pendula over 8 and 12 months, respectively. Secondly, the eight-month period showed the largest losses of leaf litter mass out of the three time periods for all four tree species. Thirdly, results showed that the total mean loss of leaf litter mass over 12 months (from December 2013 to December 2014) was significantly different between species.

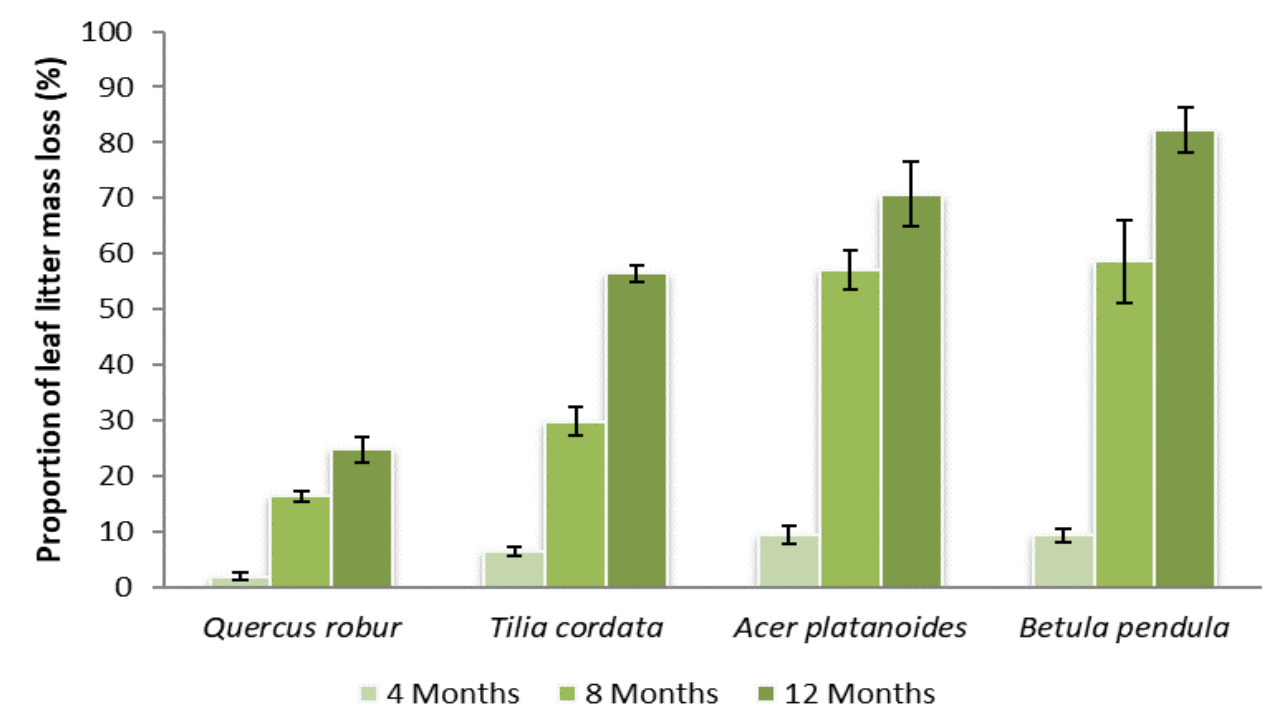

Figure 2. The combined mean proportion of leaf litter loss (mass) through decomposition for four native deciduous tree species in the urban green spaces of Kaunas, Lithuania. The first four-month period represents December to April, the eight-month period represent December to August, and the 12-month period commenced in December and finished at the end of November. The error bars represent standard error. $\mathrm{N}=15 ; 5$ green spaces $x 3$ replicates).

\subsection{Influence of Different Urban Green Spaces on Tree Species Leaf Litter Decomposition}

The initial two-factor ANOVA on urban green spaces (5 levels) and tree species (4 levels) show that, overall, there was a significant difference for both 8 months $(P<0.0001)$ and 12 months $(P<0.0001)$, respectively (Figure 3). However, over 4 months there was no overall significance $(P<0.054)$.

The subsequent non-parametric Kruskal-Wallis ANOVA test showed the following results for each tree species. 


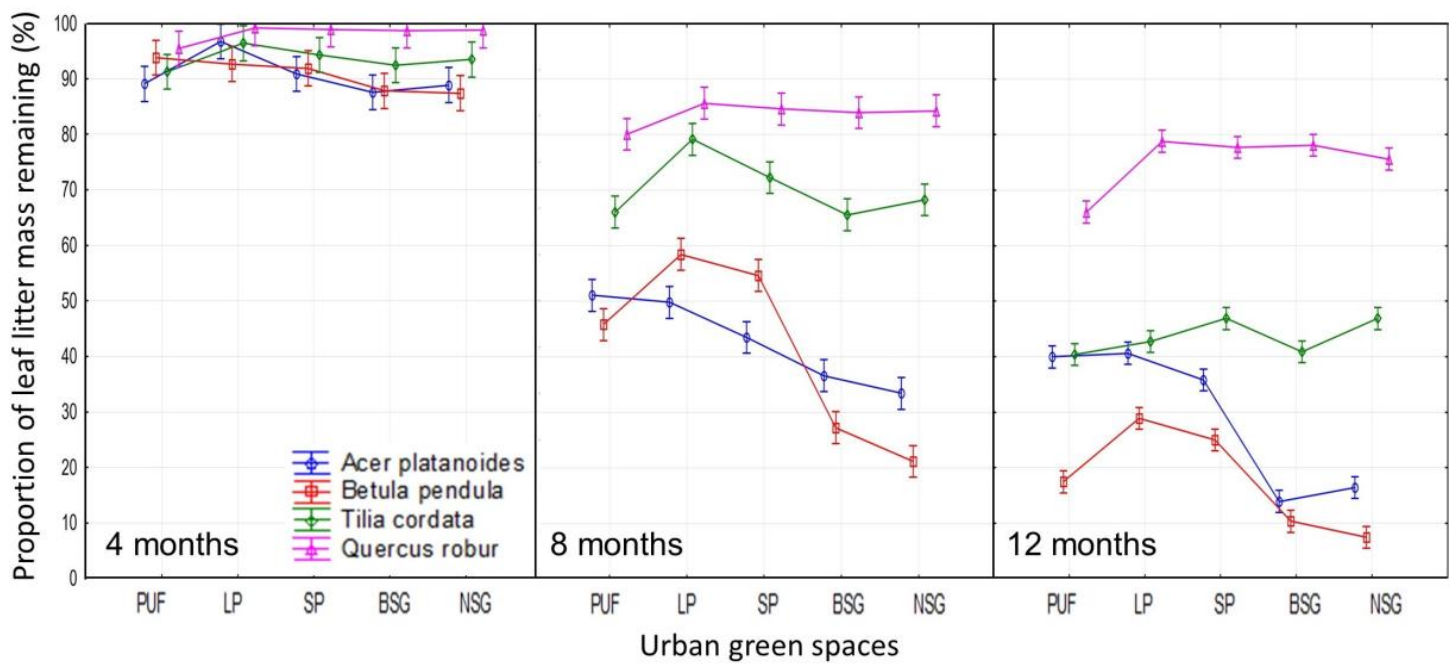

Figure 3. The mean proportion of leaf litter remaining (mass) from the 2-factor ANOVA, for four native deciduous tree species in five different types of urban green spaces in Kaunas, Lithuania. The first four-month period represents December 1st to April 1st, the eight-month period represent December 1st to August 1st, and 12 months starts in December 1st, 2013 and ends December 1st, 2014. The error bars represent $95 \%$ confidence intervals.

\section{A. platanoides}

Leaf litter decomposition of A. platanoides showed that over 4, 8, and 12 months the total amount of leaf litter loss was greatest in narrow and broad street greeneries, whereas the lowest loss leaf litter mass was recorded in large urban parks and in peri-urban forests (after 8 and 12 months) (Table 1). A. platanoides leaf litter from the broad street greeneries and narrow street greeneries recorded losses of $26 \%$ and $24 \%$ more, respectively, compared to peri-urban forest (60\%) over 12 months. The Kruskal-Wallis test showed a significant difference between leaf litter decomposition of $A$. platanoides in the different green spaces for all three time periods; 4 months $\mathrm{H}(4, \mathrm{~N}=45)=14.2 P=0.0066,8$ months $\mathrm{H}(4, \mathrm{~N}=45)=36.6 P<0.0001$, and 12 months $\mathrm{H}(4, \mathrm{~N}=45)=38.1 P<0.0001$. The leaf litter decomposition rate of $A$. platanoides peaked during the eight-month period, ranging between 10.2 (peri-urban forest) to 13.8 (narrow street greenery) mg per day (Figure 4).

Table 1. The mean leaf litter mass lost in grams for the four native deciduous trees species by the type of urban green space recorded over three time periods (4 months, 8 months, and 12 months). The $( \pm)$ represent standard error, $\mathrm{N}=3$ for the means.

\begin{tabular}{cccccc}
\hline $\begin{array}{c}\text { Urban Green } \\
\text { Spaces }\end{array}$ & $\begin{array}{c}\text { Exposure } \\
\text { (Months) }\end{array}$ & Acer Platanoides & Betula Pendula & Tilia Cordata & Quercus Robur \\
\hline Peri-urban & 4 & $0.55( \pm 0.07)$ & $0.31( \pm 0.13)$ & $0.44( \pm 0.11)$ & $0.23( \pm 0.09)$ \\
forests & 8 & $2.45( \pm 0.08)$ & $2.71( \pm 0.03)$ & $1.70( \pm 0.07)$ & $1.00( \pm 0.05)$ \\
& 12 & $3.01( \pm 0.02)$ & $4.13( \pm 0.04)$ & $2.98( \pm 0.03)$ & $1.70( \pm 0.11)$ \\
\hline Large urban & 4 & $0.17( \pm 0.05)$ & $0.37( \pm 0.14)$ & $0.18( \pm 0.07)$ & $0.04( \pm 0.02)$ \\
parks & 8 & $2.51( \pm 0.06)$ & $2.08( \pm 0.13)$ & $1.04( \pm 0.10)$ & $0.72( \pm 0.04)$ \\
& 12 & $2.97( \pm 0.03)$ & $3.56( \pm 0.07)$ & $2.86( \pm 0.04)$ & $1.06( \pm 0.08)$ \\
\hline Small urban & 4 & $0.46( \pm 0.11)$ & $0.41( \pm 0.05)$ & $0.29( \pm 0.12)$ & $0.06( \pm 0.02)$ \\
parks & 8 & $2.82( \pm 0.07)$ & $2.27( \pm 0.08)$ & $1.39( \pm 0.04)$ & $0.77( \pm 0.08)$ \\
& 12 & $3.21( \pm 0.04)$ & $3.75( \pm 0.03)$ & $2.66( \pm 0.05)$ & $1.11( \pm 0.07)$ \\
\hline Broad street & 4 & $0.62( \pm 0.09)$ & $0.61( \pm 0.06)$ & $0.38( \pm 0.08)$ & $0.07( \pm 0.02)$ \\
greeneries & 8 & $3.17( \pm 0.02)$ & $3.64( \pm 0.06)$ & $1.72( \pm 0.10)$ & $0.80( \pm 0.04)$ \\
& 12 & $4.30( \pm 0.03)$ & $4.48( \pm 0.02)$ & $2.96( \pm 0.03)$ & $1.10( \pm 0.03)$ \\
\hline \multirow{2}{*}{ Narrow street } & 4 & $0.56( \pm 0.06)$ & $0.63( \pm 0.04)$ & $0.33( \pm 0.06)$ & $0.06( \pm 0.01)$ \\
greeneries & 8 & $3.33( \pm 0.03)$ & $3.94( \pm 0.04)$ & $1.59( \pm 0.12)$ & $0.79( \pm 0.10)$ \\
& 12 & $4.18( \pm 0.02)$ & $4.63( \pm 0.02)$ & $2.66( \pm 0.06)$ & $1.22( \pm 0.06)$ \\
\hline
\end{tabular}




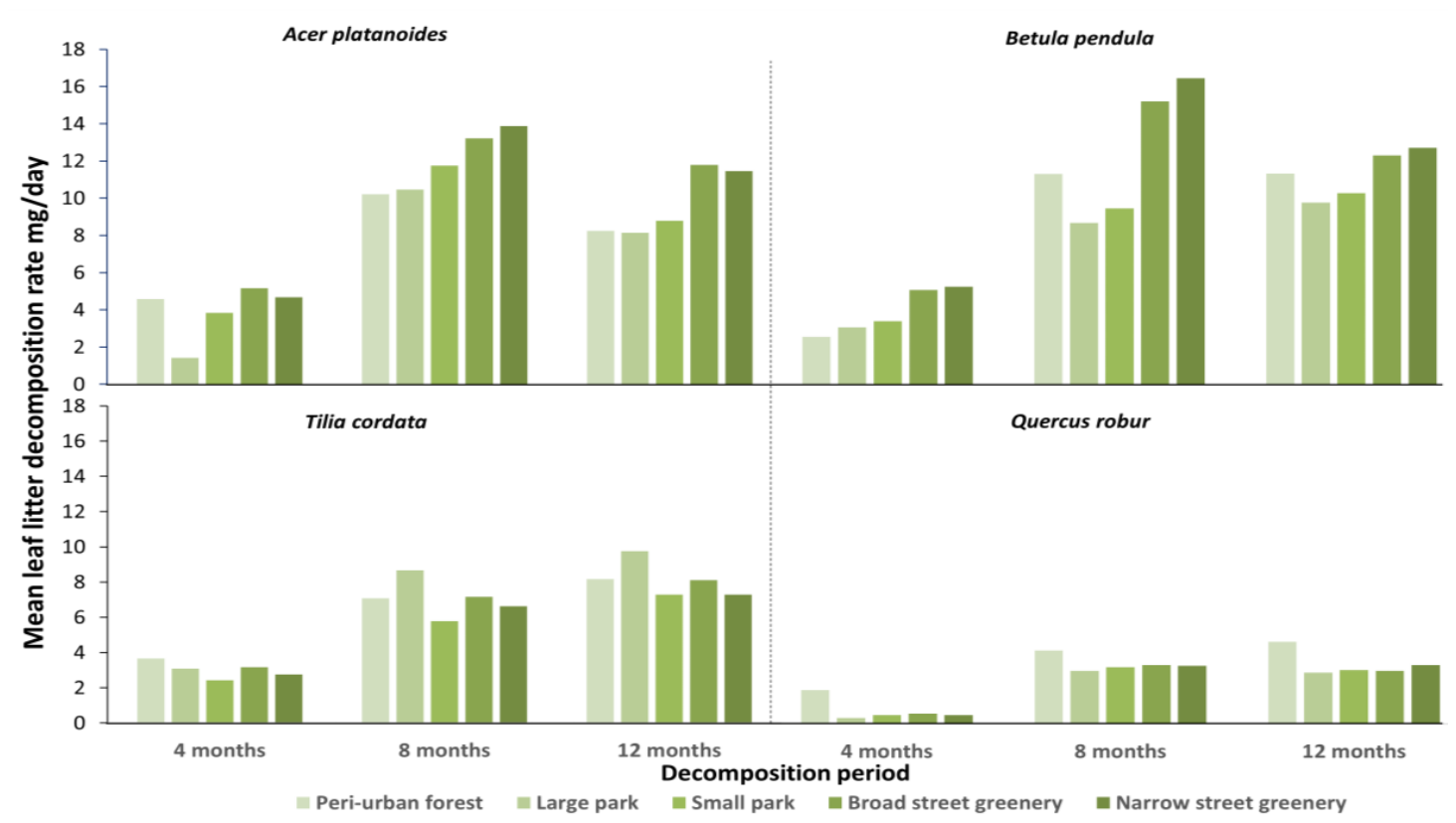

Figure 4. The mean daily decomposition rate of four different deciduous leaf litter types from five urban greens spaces over 4, 8, and 12 months, respectively, in Kaunas, Lithuania.

\section{B. pendula}

Results of B. pendula leaf litter decomposition showed that over 4, 8, and 12 months, decomposition of leaf litter loss was greatest in narrow street greeneries and broad street greeneries (Table 1). After 4 months, the lowest loss of B. pendula leaf litter mass was recorded in the peri-urban park; however, after 8 months and 12 months, large parks recorded the lowest loss of leaf litter mass (Table 1). The Kruskal-Wallis test showed a significant difference between leaf litter decomposition of B. pendula in the different green spaces for both the eight-month $(\mathrm{H}(4, \mathrm{~N}=45)=39.9 P<0.0001)$ and twelve-month $(\mathrm{H}(4, \mathrm{~N}=45)=40.4 P<0.0001)$ periods. There was no significant difference between decomposition of leaf litter in the urban green spaces for the first four months $(\mathrm{H}(4, \mathrm{~N}=45)=5.8 P=0.2149)$. The leaf litter decomposition rate of $B$. pendula peaked during the eight-month period, ranging between 8.4 (large parks) to 16.7 (narrow street greenery) mg per day (Figure 4).

\section{T. cordata}

Results of T. cordata litter decomposition showed that over 4, 8, and 12 months the total amount of leaf litter loss was greatest in peri-urban forests followed by broad street greeneries. After 4 and 8 months, the lowest loss leaf litter mass was recorded in large urban parks, and after 12 months in small urban parks (Table 1). After 12 months, T. cordata lost between $52 \%-60 \%$ of litter mass for all green space types. These results showed the least variation between the different green spaces (Figure 3). The Kruskal-Wallis test showed a significant difference between leaf litter decomposition of $T$. cordata in the different green spaces for both the eight-month $(\mathrm{H}(4, \mathrm{~N}=45)=20.9 P=0.003)$ and twelve-month $(\mathrm{H}(4, \mathrm{~N}=45)=23.9 P<0.0001)$ periods. There was no significant difference between decomposition of leaf litter in the urban green spaces for the first four-month period $(\mathrm{H}(4, \mathrm{~N}=45)=7.7$ $P=0.1042)$. The leaf litter decomposition rate of $T$. cordata peaked during the twelve-month period, ranging between 7.3 (small parks) to 9.8 (large parks) mg per day (Figure 4).

Q. robur

Results of Q. robur leaf litter decomposition showed that over 4, 8, and 12 months the total amount of leaf litter loss was greatest in peri-urban forests. The leaf litter decomposition of the other green space types was similar, with only a $0.08 \%$ difference. (Table 1 ). After 12 months, leaf litter mass lost 
in peri-urban forest significantly differed from all other urban green spaces. The Kruskal-Wallis test showed a significant difference between leaf litter decomposition of $Q$. robur in the different green spaces for both the eight-month $(\mathrm{H}(4, \mathrm{~N}=45)=9.7 \mathrm{P}=0.0463)$ and twelve-month $(\mathrm{H}(4, \mathrm{~N}=45)$ $\mathrm{H}=19.7 \mathrm{P}=0.0006)$ periods. There was no significant difference between the decomposition of leaf litter in the different urban green spaces for the first four-month period $(\mathrm{H}(4, \mathrm{~N}=45)=4.9 \mathrm{p}=0.2958)$. The leaf litter decomposition rate of $Q$. robur peaked relatively slowly compared to the other species during all periods, peaking over the twelve-month period with a range of 2.9 (large parks) to 4.7 (peri-urban forests) mg per day (Figure 4).

\subsection{Leaf Litter C:N, C:P, and N:P Ratios}

B. pendula leaf litter recorded the highest $\mathrm{C}: \mathrm{N}$ ratios from broad street greeneries $\left(59.2 \mathrm{~g} \mathrm{~g}^{-1}\right)$ and from large urban parks $\left(58 \mathrm{~g} \mathrm{~g}^{-1}\right)$. The lowest $\mathrm{C}: \mathrm{N}$ ratios were recorded in the peri-urban forests $\left(42 \mathrm{~g} \mathrm{~g}^{-1}\right)$. These differences were significant. In contrast, the leaf litter of $T$. cordata from all greeneries showed the lowest C:N ratio (30-35.2 $\mathrm{g} \mathrm{g}^{-1}$ ) (Table 2).

Table 2. Mean ratios of carbon to nitrogen $\left(\mathrm{C}: \mathrm{N}\left(\mathrm{g} \mathrm{g}^{-1}\right)\right)$, carbon to phosphorus (C:P $\left.\left(\mathrm{g} \mathrm{g}^{-1}\right)\right)$, and nitrogen to phosphorus (N:P $\left(\mathrm{g} \mathrm{g}^{-1}\right)$ ), recorded in the leaf litter of four native deciduous tree species from five different urban green spaces (PUF = peri-urban forest, $\mathrm{LP}=$ large urban park, $\mathrm{SP}=$ small urban park, BSG = broad street greenery, and NSG = narrow street greenery) in Kaunas, Lithuania. The $( \pm)$ represent standard error, $\mathrm{N}=3$ for the means.

\begin{tabular}{cccccc}
\hline Tree Species & PUF & LP & SP & BSG & NSG \\
\hline C:N (g g $^{-1}$ ) & & & & & \\
Acer platanoides & $45.2 \pm 1.8$ & $43.8 \pm 0.4$ & $43.0 \pm 0.3$ & $40.4 \pm 1.7$ & $39.2 \pm 0.2$ \\
Betula pendula & $42.0 \pm 3.7$ & $58.0 \pm 0.1$ & $41.3 \pm 3.8$ & $59.2 \pm 1.9$ & $53.0 \pm 0.4$ \\
Tilia cordata & $32.0 \pm 0.4$ & $35.2 \pm 0.3$ & $30.8 \pm 0.2$ & $31.0 \pm 0.2$ & $30.0 \pm 2.6$ \\
Quercus robur & $40.5 \pm 1.9$ & $39.4 \pm 0.1$ & $40.3 \pm 0.9$ & $36.3 \pm 0.8$ & $38.5 \pm 0.8$ \\
C:P (g g $^{-1}$ ) & & & & & \\
Acer platanoides & $809 \pm 64$ & $498 \pm 3$ & $426 \pm 8$ & $537 \pm 33$ & $487 \pm 26$ \\
Betula pendula & $632 \pm 29$ & $240 \pm 11$ & $256 \pm 18$ & $244 \pm 12$ & $342 \pm 9$ \\
Tilia cordata & $550 \pm 14$ & $480 \pm 12$ & $401 \pm 20$ & $484 \pm 9$ & $590 \pm 66$ \\
Quercus robur & $777 \pm 17$ & $583 \pm 17$ & $329 \pm 20$ & $525 \pm 22$ & $872 \pm 10$ \\
$\quad$ N:P (g g $\mathbf{- 1}$ ) & & & & & \\
Acer platanoides & $17.9 \pm 1.1$ & $11.4 \pm 0.3$ & $9.9 \pm 0.2$ & $13.3 \pm 0.5$ & $12.4 \pm 1.0$ \\
Betula pendula & $15.4 \pm 2.1$ & $4.1 \pm 0.03$ & $6.5 \pm 1.8$ & $4.1 \pm 0.1$ & $6.5 \pm 0.4$ \\
Tilia cordata & $17.2 \pm 0.5$ & $13.7 \pm 0.3$ & $13 \pm 1.0$ & $15.5 \pm 0.3$ & $19.6 \pm 0.9$ \\
Quercus robur & $19.2 \pm 0.6$ & $14.8 \pm 0.7$ & $8.1 \pm 0.6$ & $14.4 \pm 0.5$ & $22.7 \pm 0.4$ \\
\hline
\end{tabular}

Q. robur leaf litter from narrow street greeneries and large parks $\left(583 \mathrm{~g} \mathrm{~g}^{-1}\right)$ and A. platanoides from peri-urban forest $\left(809 \mathrm{~g} \mathrm{~g}^{-1}\right)$, recorded the highest C:P ratio. In contrast, B. pendula leaf litter recorded the lowest C:P ration from the large urban parks $\left(240 \mathrm{~g} \mathrm{~g}^{-1}\right)$ (Table 2). The leaf litter of A. platanoides showed the largest C:P ration difference $\left(383 \mathrm{~g} \mathrm{~g}^{-1}, \mathrm{P}=0.010\right)$ between peri-urban forests and small urban parks.

Q. robur leaf litter generally showed the highest $\mathrm{N}: \mathrm{P}$ ratios as following: peri-urban forests $\left(19.9 \mathrm{~g} \mathrm{~g}^{-1}\right)$, narrow street greeneries $\left(22.7 \mathrm{~g} \mathrm{~g}^{-1}\right)$, and large urban parks $\left(14.8 \mathrm{~g} \mathrm{~g}^{-1}\right)$. The leaf litter of B. pendula from all greeneries showed the lowest $\mathrm{N}: \mathrm{P}$ ratio, ranging between $4.1-15.4 \mathrm{~g} \mathrm{~g}^{-1}$.

\section{Discussion}

\subsection{Leaf Litter Decomposition in Time and Space}

Overall, our study shows that there is large variation in the decomposition of leaf litter between urban green spaces, tree species, and in time (seasonal). This supports Jacob et al. [36], in that there are differences between the three diversity levels regarding leaf litter decomposition from individual tree 
species. Firstly, results show that leaf litter decomposition is influenced by tree species, with B. pendula showing the highest rate of decay, followed by A. platanoides, T. cordata, and Q. robur. We found that the decomposition of leaf litter by seasonality and time (4, 8, and 12 months) was significantly different. The smallest losses in mass occurred during the first four-month interval (the winter period), with Q. robur only losing $1.8 \%$ and A. platanoides losing the most with $9.4 \%$. This may be attributed to atmospheric and soil temperatures as they were largely sub-zero during winter, thus restricting the activity of microorganisms.

In comparison, leaf litter decomposition over 8 months was more intensive for all tree species. This may be caused by changes in climatic condition from winter-spring to spring-summer in the second four-month interval in which microorganism activity increased. The highest losses in mass were recorded during the four- to eight-month interval for all species except $T$. cordata. Leaf litter of Q. robur lost $16.3 \%$ of mass; this is nine times more compared to the first four-month period. Leaf litter of B. pendula had the biggest reduction in mass of $58.6 \%$; this was six times more, compared to the four-month period. Therefore, our results support the notion that the spring-summer period is an important period for nutrient discharge back into the local environments or as run-off into the local river systems [14]. Moreover, the spring-summer period is important for trees to obtain ample nutrients to stimulate growth and flowering. Indeed, this study shows leaf litter decomposition is an important nutrient source that enriches the soil during the spring period.

After 12 months, leaf litter decomposition slowed for all species except T. cordata. In total, B. pendula and A. platanoides lost the most mass; $82 \%$ and $70 \%$, respectively. B. pendula only lost 1.4 times more compared to the mass loss for 8 months. The high decomposition of $B$. pendula leaf litter obtained in this study was consistent with the findings of Cotrufo et al. [37] but much higher than results found in other European cities. Unlike any of the other species, T. cordata leaf litter decomposition showed increased decomposition through all urban green spaces. The increased levels of leaf litter decomposition can provide additional and continuous nutrient enrichment to the soil if combined with other species. However, $Q$. robur only lost $24.7 \%$ of its leaf litter mass, in comparison this was only 1.5 times more than its loss after 8 months and well below the leaf litter decomposition of the other three species (Figure 2). Our results suggest that, for the leaf litter of $Q$. robur, 12 months does not provide enough time for its leaf litter to decompose, thus its contribution to providing nutrients back into the soil or as run-off over this time span is minimal in urban green spaces.

\subsection{Leaf Litter Decomposition in Different Urban Green Spaces}

The leaf litter of B. pendula and A. platanoides from street green spaces showed the highest losses in leaf litter overall. $Q$. robur leaf litter decomposition showed small but significant differences between the urban green spaces, and the decomposition of $T$. cordata leaf litter showed no significance between the types of green spaces. Our findings are consistent with the results of Dorendorf et al. [38] that leaf litter decomposition for peri-urban forest is slower compared to the other urban green spaces for A. platanoides and B. pendula but not for Q. robur and T. cordata. The rate of leaf litter decomposition has been shown to be an indicator of leaf quality, with faster increased rates of decomposition indicating poorer quality (i.e., less nutrients) [39]. In addition, previous research has shown that different leaf litter decomposition rates are due to environmental variability. For instance, leaf litter decomposition can be more rapid in urban areas because of higher temperatures, greater nutrient availability (e.g., soil fertilization), and an increased abundance of earthworms, as well as different soil substrate and $\mathrm{pH}$ [40-43]. However, Rawlik et al. [44] found that higher soil temperature may lead to reduced moisture and slower leaf litter decomposition.

Q. robur leaf litter decay was the slowest over 12 months, with only $22 \%-26 \%$ of its leaf litter mass lost within the five different urban green spaces. This is consistent with the notion that $Q$. robur leaf litter is of a lower quality and therefore decomposes relatively slowly [45-47]. Our results showed that $Q$. robur leaf litter from peri-urban forests decayed $12 \%$ faster over 12 months compared to leaf litter from the other urban green spaces. The results of other studies with red oak (Quercus rubra) 
decomposition suggest that litter from the urban forests decayed $25 \%$ slower than leaf litter of rural areas [21]. Previous studies on introduced Q. robra leaf litter decomposition in Kaunas's urban parks have not shown significant differences between different environmental conditions [48]. Our results show that $Q$. robur litter decomposition from four of the five different types of green spaces were not significantly different. This is similar to the results of Straigyte et al. [49] for leaf litter decomposition of Q. robur in small urban parks after 12 months. In contrast, this study found a $19 \%$ increase in leaf litter loss for $A$. platanoides over 12 months compared to the 2009 results [49]. This suggests that A. platanoides is sensitive to environmental change, but further studies would be needed to confirm the environmental changes within Kaunas.

\subsection{Leaf Litter C:N, C:P and N:P Ratio}

Litter decomposition is controlled by factors such as climate, litter quality, and soil decomposing organisms $[17,24]$. In our experiment, we used a controlled environment to limit the variation of climate and soil on the decomposition of the leaf litter samples. Thus, there was only a difference in leaf litter species, collection location, type of green space, and leaf litter quality. High levels of nutrients, especially $\mathrm{N}$, lead to faster decomposition [50]. However, results from boreal forest show that decomposition intensity is negatively correlated to the C:N ratio of leaf litter [51]. We found that rising $\mathrm{N}$ concentrations in $\mathrm{Q}$. robur leaf litter increased the rate of leaf litter decomposition compared to the study of Janusauskaite and Straigyte [27].

Rapid decomposition of B. pendula and A. platanoides leaf litter from street greeneries indicates in this study that these species may be the most appropriate to deliver important nutrients back into the soil. The loss of $\mathrm{C}$ and $\mathrm{N}$ via leaf litter removal in urban green spaces can create nutrient limitations for some vegetation due to diminished opportunities to recycle nutrients [52]. In addition, artificial ground surfaces within urban areas around green spaces can create barriers for soil enrichment (e.g., street greeneries) [53]. Thus, the entry of nutrients back into the soil profiles of green spaces is very crucial and a critical component for optimal tree growth.

Research on leaf litter from woodlands in the Netherlands found that leaf litter concentrations of $C$ and $P$ were significantly correlated with the rate of litter decomposition [54]. We found that the $\mathrm{C}: \mathrm{P}$ ratio also differed between tree species and some green spaces. The biggest C:P ratio variation $\left(543 \mathrm{~g} \mathrm{~g}^{-1}\right)$ was recorded for $Q$. robur leaf litter between urban forests and small parks. The differences between large parks and broad street greeneries were not significant. Our study shows that the variation between the decomposition rates of leaf litter from different types of green spaces may be because leaf quality is affected by urban environments. However, the decomposition of leaf litter can be negatively influenced by the foliar uptake of atmospheric pollutants, and indirectly through alterations in local climate and changes in soil fertility caused by pollutant loads and altered nutrient cycling regimes. For instance, Varnagirytė-Kabašinskiene et al. [55] found that the leaf litter of both Q. robur and T. cordata had large nutrient fluxes. This may explain the slow decomposition of the Q. robur and T. cordata leaf litter found in our research. However, results on leaf litter decomposition can be difficult to interpret directly due to two main causes. Firstly, the differences in leaf decomposition between different urban green spaces may vary, and under normal conditions green spaces contain mixed plant communities and thus mixed litter types. Secondly, soil characteristics (such as soil communities, $\mathrm{pH}$, and soil quality) in combination with litter quality may cause different trends in the leaf litter decomposition of different green spaces. Indeed, Straigyte et al. [41] found a negative correlation between leaf litter decomposition in peri-urban forests and acidic soils with a low N:P ratio.

\subsection{Planning of Urban Green Space}

Currently, the Kaunas city municipality uses T. cordata in their replacement program for street greeneries. Our study supports the inclusion of A. platanoides, B. pendula, and Q. robur in their replacement program. However, as a study shows, understanding the decomposition of leaf litter can help city planners select the most suitable tree species and maintenance programs (for example, leaf 
litter collection and soil fertilization) for each urban green space. The slow decomposition of $Q$. robur and T. cordata can be appropriate in areas with high artificial surfaces where nutrients cannot penetrate back into the soil profile or nutrient run-off should be prevented. Whereas the rapid decomposition of B. pendula and A. platanoides leaf litter indicates that these species are best suited for growing in urban green spaces where a rapid replenishment of soil nutrients are needed. Thus, the results of our study on leaf litter decomposition from different urban green spaces may provide city planners in Lithuania, with similar species and environmental conditions, knowledge on how urban environments affect leaf litter decomposition.

Although this study focused on only four commonly found deciduous tree species, we advocate the use of all native trees currently found in the green spaces of Kaunas as this would help maintain both natural ecological processes and the current levels of biodiversity that are both important for delivering benefits to human well-being.

In conclusion, our research results show that leaf litter decomposition, as an environmental process, was significantly different between seasonality (time duration of 8 and 12 months), tree species, leaf litter nutrient release, and the types of green spaces. Firstly, the highest level of leaf litter decomposition was recorded during the spring season (between 4-8 months). Secondly, there were large difference between the leaf litter decomposition of the four deciduous tree species (B. pendula, the fastest, and $Q$. robur, the slowest). Thirdly, we found significant differences in C:N, C:P, and N:P ratios between leaf litter decomposition and nutrient level for the five different types of green urban spaces. Q. robur showed accelerated leaf litter decay when the C:N ratio decreased. This study highlights the complexity of urban environments and that more research on the processes of leaf litter decomposition using multiple species or mixed species, and with different environmental characteristic across various cities, are needed to further understand the processes and mechanisms of litter decomposition and nutrient dynamics in urban environments.

Author Contributions: T.V. and L.S. conceived and designed the experiments and performed the field work. T.V., L.S., and M.M. analyzed the data and wrote the paper. All authors have read and agreed to the published version of the manuscript.

Funding: This research received no external funding.

Conflicts of Interest: The authors declare no conflict of interest.

\section{References}

1. Sachweh, M.; Rötzer, T. Climatic Change Effects on Phenological Phases in Southern Germany. In Proceedings of the 14th International Congress of Biometeorolgy, Ljubljana, Slovenia, 1-8 September 1996; pp. 226-233.

2. Rötzer, T.; Sachweh, M. Climatic changes as reflected in phenological time series. Arboreta Phänologica 1995, $40,17-23$.

3. Haines-Young, R.; Potschin, M. The links between biodiversity, ecosystem services and human well-being. Ecosyst. Ecol. New Synth. 2010, 1, 110-139.

4. Walker, T.D. Functional and aesthetic uses of plants in design. In Plants in the Landscape, 2nd ed.; Carpenter, P.L., Walker, T.D., Eds.; WH Freeman: New York, NY, USA, 1990; pp. 152-178.

5. Roy, S.; Byrne, J.; Pickering, C. A systematic quantitative review of urban tree benefits, costs, and assessment methods across cities in different climatic zones. Urban For. Urban Green. 2012, 11, 351-363. [CrossRef]

6. Fuller, R.A.; Gaston, K.J. The scaling of green space coverage in European cities. Biol. Lett. 2009, 5, 352-355. [CrossRef]

7. Takács, Á.; Kiss, M.; Hof, A.; Tanács, E.; Gulyás, Á.; Kántor, N. Microclimate Modification by Urban Shade Trees-An Integrated Approach to Aid Ecosystem Service Based Decision-making. Procedia Environ. Sci. 2016, 32, 97-109. [CrossRef]

8. Bradshaw, A.; Hunt, B.; Walmsley, T. Trees in the Urban Landscape: Principles and Practice; Taylor \& Francis: London, UK, 1995; p. 288.

9. Ruark, G.A.; Mader, D.L.; Tattar, T.A. The influence of soil compaction and aeration on the root growth and vigour of trees-a literature review. Part 1. Arboric. J. 1982, 6, 251-265. [CrossRef] 
10. Pauleit, S.; Jones, N.; Garcia-Martin, G.; Garcia-Valdecantos, J.L.; Rivière, L.M.; Vidal-Beaudet, L.; Bodson, M.; Randrup, T.B. Tree establishment practice in towns and cities-Results from a European survey. Urban For. Urban Green. 2002, 1, 83-96. [CrossRef]

11. Enloe, H.A.; Lockaby, B.G.; Zipperer, W.C.; Somers, G.L. Urbanization effects on leaf litter decomposition, foliar nutrient dynamics and aboveground net primary productivity in the subtropics. Urban Ecosyst 2015, 18, 1285-1303. [CrossRef]

12. Vaidelys, T.; Straigytè, L. Length of grow season for native tree species in different green spaces. Žemés Moksl. 2017, 24, 62-71. [CrossRef]

13. Boyero, L.; Pearson, R.G.; Gessner, M.O.; Barmuta, L.A.; Ferreira, V.; Graça, M.A.S.; Dudgeon, D.; Boulton, A.J.; Callisto, M.; Chauvet, E.; et al. A global experiment suggests climate warming will not accelerate litter decomposition in streams but might reduce carbon sequestration. Ecol. Lett. 2011, 14, 289-294. [CrossRef] [PubMed]

14. Hobbie, S.E.; Baker, L.A.; Buyarski, C.; Nidzgorski, D.; Finlay, J.C. Decomposition of tree leaf litter on pavement: Implications for urban water quality. Urban Ecosyst. 2014, 17, 369-385. [CrossRef]

15. García-Palacios, P.; McKie, B.G.; Handa, I.T.; Frainer, A.; Hättenschwiler, S. The importance of litter traits and decomposers for litter decomposition: A comparison of aquatic and terrestrial ecosystems within and across biomes. Funct. Ecol. 2016, 30, 819-829. [CrossRef]

16. Waring, R.; Schlesinger, W. Decomposition and Forest Soil Development; Academic Press: Orlando, FL, USA, 1985; pp. 181-208.

17. Couteaux, M.-M.; Bottner, P.; Berg, B. Litter decomposition, climate and liter quality. Trends Ecol. Evol. 1995, 10, 63-66. [CrossRef]

18. Zhang, D.; Hui, D.; Luo, Y.; Zhou, G. Rates of litter decomposition in terrestrial ecosystems: Global patterns and controlling factors. J. Plant Ecol. 2008, 1, 85-93. [CrossRef]

19. Sariyildiz, T.; Anderson, J.M. Interactions between litter quality, decomposition and soil fertility: A laboratory study. Soil Biol. Biochem. 2003, 35, 391-399. [CrossRef]

20. Aubert, M.; Margerie, P.; Trap, J.; Bureau, F. Aboveground-belowground relationships in temperate forests: Plant litter composes and microbiota orchestrates. Forest Ecol. Manag. 2010, 259, 563-572. [CrossRef]

21. Carreiro, M.M.; Howe, K.; Parkhurst, D.F.; Pouyat, R.V. Variation in quality and decomposability of red oak leaf litter along an urban-rural gradient. Biol. Fertil. Soils 1999, 30, 258-268. [CrossRef]

22. Taylor, B.R.; Jones, H.G. Litter decomposition under snow cover in a balsam fir forest. Can. J. Bot. 1990, 68, 112-120. [CrossRef]

23. Averill, C.; Waring, B. Nitrogen limitation of decomposition and decay: How can it occur? Glob. Chang. Biol. 2018, 24, 1417-1427. [CrossRef]

24. Aerts, R. Climate, leaf litter chemistry and leaf litter decomposition in terrestrial ecosystems. Oikos 1997, 79, 439-449. [CrossRef]

25. Pérez-Harguindeguy, N.; Díaz, S.; Cornelissen, J.H.C.; Vendramini, F.; Cabido, M.; Castellanos, A. Chemistry and toughness predict leaf litter decomposition rates over a wide spectrum of functional types and taxa in central Argentina. Plant Soil 2000, 218, 21-30. [CrossRef]

26. Wang, Q.; Wang, S.; Huang, Y. Comparisons of litterfall, litter decomposition and nutrient return in a monoculture Cunninghamia lanceolata and a mixed stand in southern China. Forest Ecol. Manag. 2008, 255, 1210-1218. [CrossRef]

27. Janusauskaite, D.; Straigyte, L. Leaf litter decomposition differences between alien and native maple species. Baltic. For. 2011, 17, 189-196.

28. Gartner, T.B.; Cardon, Z.G. Decomposition dynamics in mixed-species leaf litter. Oikos 2004, 104, $230-246$. [CrossRef]

29. Martínez-Yrízar, A.; Núñez, S.; Búrquez, A. Leaf litter decomposition in a southern Sonoran Desert ecosystem, northwestern Mexico: Effects of habitat and litter quality. Acta Oecol. 2007, 32, 291-300. [CrossRef]

30. Månsson, K.F.; Falkengren-Grerup, U. The effect of nitrogen deposition on nitrification, carbon and nitrogen mineralisation and litter C:N ratios in oak (Quercus robur L.) forests. For. Ecol. Manag. 2003, 179, 455-467. [CrossRef]

31. Bärlocher, F. Leaf Mass Loss Estimated by Litter Bag Technique. In Methods to Study Litter Decomposition: A Practical Guide; Graça, M.A.S., Bärlocher, F., Gessner, M.O., Eds.; Springer: Berlin/Heidelberg, Germany, 2005; pp. 37-42.

32. Crossley, D.A., Jr.; Hoglund, M.P. A Litter-Bag Method for the Study of Microarthropods Inhabiting Leaf Litter. Ecology 1962, 43, 571-573. [CrossRef] 
33. McKight, P.E.; Najab, J. Kruskal-Wallis Test. In The Corsini Encyclopedia of Psychology; Weiner, I.B., Craighead, W.E., Eds.; John Wiley \& Sons: Hoboken, NJ, USA, 2010.

34. Gotelli, N.; Ellison, A. A Primer of Ecological Statistics, 2nd ed.; Sinauer Associates: Sunderland, MA, USA, 2013.

35. Kruskal, W.H.; Wallis, W.A. Use of Ranks in One-Criterion Variance Analysis. J. Am. Stat. Assoc. 1952, 47, 583-621. [CrossRef]

36. Jacob, M.; Weland, N.; Platner, C.; Schaefer, M.; Leuschner, C.; Thomas, F.M. Nutrient release from decomposing leaf litter of temperate deciduous forest trees along a gradient of increasing tree species diversity. Soil Biol. Biochem. 2009, 41, 2122-2130. [CrossRef]

37. Cotrufo, F.M.; Ineson, P.; Derek Roberts, J. Decomposition of birch leaf litters with varying C-to-N ratios. Soil Biol. Biochem. 1995, 27, 1219-1221. [CrossRef]

38. Dorendorf, J.; Wilken, A.; Eschenbach, A.; Jensen, K. Urban-induced changes in tree leaf litter accelerate decomposition. Ecol. Process. 2015, 4, 1. [CrossRef]

39. Hossain, M.; Siddique, M.R.H.; Rahman, M.S.; Hossain, M.Z.; Hasan, M.M. Nutrient dynamics associated with leaf litter decomposition of three agroforestry tree species (Azadirachta indica, Dalbergia sissoo, and Melia azedarach) of Bangladesh. J. For. Res. 2011, 22, 577. [CrossRef]

40. Imberger, S.J.; Walsh, C.J.; Grace, M.R. More microbial activity, not abrasive flow or shredder abundance, accelerates breakdown of labile leaf litter in urban streams. J. North Am. Benthol. Soc. 2008, 27, 549-561. [CrossRef]

41. Straigytè, L.; Vaidelys, T.; Manton, M. Impact of urban green spaces, native tree species and seasons on soil pH in Kaunas, Lithuania. Baltic For. 2019, 25, 257-262.

42. Pouyat, R.V.; Carreiro, M.M. Controls on mass loss and nitrogen dynamics of oak leaf litter along an urban-rural land-use gradient. Oecologia 2003, 135, 288-298. [CrossRef]

43. Pouyat, R.V.; McDonnell, M.J.; Pickett, S.T. Litter decomposition and nitrogen mineralization in oak stands along an urban-rural land use gradient. Urban Ecosyst. 1997, 1, 117-131. [CrossRef]

44. Rawlik, M.; Kasprowicz, M.; Jagodziński, A.M.; Rawlik, K.; Kaźmierowski, C. Slope exposure and forest stand type as crucial factors determining the decomposition rate of herbaceous litter on a reclaimed spoil heap. Catena 2019, 175, 219-227. [CrossRef]

45. Blair, J.M.; Crossley, D., Jr. Litter decomposition, nitrogen dynamics and litter microarthropods in a southern Appalachian hardwood forest 8 years following clearcutting. J. Appl. Ecol. 1988, 683-698. [CrossRef]

46. Heneghan, L.; Coleman, D.C.; Zou, X.; Crossley, D., Jr.; Haines, B. Soil microarthropod contributions to decomposition dynamics: Tropical-temperate comparisons of a single substrate. Ecology 1999, 80, 1873-1882.

47. Heneghan, L.; Rauschenberg, C.; Fatemi, F.; Workman, M. European buckthorn (Rhamnus cathartica) and its effects on some ecosystem properties in an urban woodland. Ecol. Restor. 2004, 22, 275-280. [CrossRef]

48. Straigyté, L.; Zalkauskas, R. Effect of climate variability on Quercus rubra phenotype and spread in Lithuanian forests. Dendrobiology 2012, 67, 79-85.

49. Straigytė, L.; Jurkšienè, G.; Armolaitis, K. Decomposition of Oak and Maple Leaf Litters: Comparative Study of Native and Alien Species. Sustain. Dev. For. 2009, 4, 196-200.

50. Jonsson, M.; Wardle, D.A. Context dependency of litter-mixing effects on decomposition and nutrient release across a long-term chronosequence. Oikos 2008, 117, 1674-1682. [CrossRef]

51. Kurka, A.M.; Starr, M.; Heikinheimo, M.; Salkinoja-Salonen, M. Decomposition of cellulose strips in relation to climate, litterfall nitrogen, phosphorus and C/N ratio in natural boreal forests. Plant Soil 2000, 219, 91-101. [CrossRef]

52. Templer, P.H.; Toll, J.W.; Hutyra, L.R.; Raciti, S.M. Nitrogen and carbon export from urban areas through removal and export of litterfall. Environ. Pollut. 2015, 197, 256-261. [CrossRef]

53. Scalenghe, R.; Marsan, F.A. The anthropogenic sealing of soils in urban areas. Landsc. Urban Plan. 2009, 90, 1-10. [CrossRef]

54. Hoorens, B.; Aerts, R.; Stroetenga, M. Does initial litter chemistry explain litter mixture effects on decomposition? Oecologia 2003, 137, 578-586. [CrossRef]

55. Varnagirytè-Kabašinskienè, I.; Hagen-Thorn, A.; Armolaitis, K. Comparative study of litterfall in different deciduous species plantations. Miškininkystė 2005, 1, 30-36.

(C) 2020 by the authors. Licensee MDPI, Basel, Switzerland. This article is an open access article distributed under the terms and conditions of the Creative Commons Attribution (CC BY) license (http://creativecommons.org/licenses/by/4.0/). 